\title{
Magma evolution and PGE mineralization in the Late Neoproterozoic Mechanic Settlement Pluton, southern New Brunswick
}

\author{
Russel S. Hiebert ${ }^{1 *}$ Sandra M. Barr,${ }^{1} \dagger$ and Clifford R. Stanley ${ }^{1}$ \\ 1. Department of Earth and Environmental Science, Acadia University, Wolfville, Nova Scotia B4P 2R6, Canada \\ $\dagger$ Corresponding author:<sandra.barr@acadiau.ca> \\ *Present address: FNX Mining Company Inc., 1300 Kelly Lake Road, Sudbury, Ontario P3E 5P4, Canada
}

Date received 8May 2008 gate accepted 28 July 2008

\begin{abstract}
The Mechanic Settlement Pluton, southern New Brunswick, is a high-level mafic-ultramafic pluton of Late Neoproterozoic age (ca. $557 \mathrm{Ma}$ ). Based on surface-outcrop and drill-core samples, the pluton includes six different lithologic assemblages: peridotitic, olivine-bearing gabbroic, gabbroic, anorthositic, troctolitic, and dioritic, each of which consists of a range of related rock types. Cumulate textures are typically present, and several rock types contain interstitial hydrous silicate minerals, indicating a wet parent magma. The general mineral crystallization sequence in the pluton was olivine and chromite, plagioclase, clinopyroxene, orthopyroxene, and a hydrous mafic silicate mineral (either phlogopite or hornblende). Lithologic assemblages and their constituent varieties are not continuous between drill holes, and no statistically significant pattern in the stratigraphic succession could be established with the available data. Variation in the mineralogy and chemistry of the rocks is controlled by fractionation of olivine and plagioclase. The Mechanic Settlement Pluton and comagmatic Coldbrook Group basalt are probably of calc-alkaline affinity. Several horizons bearing platinum-group elements associated with minor sulphide mineralization (pyrrhotite-chalcopyrite-pentlandite) occur in peridotitic rocks, which may have formed during or following magma influx. Based on similarities to the Lac des Iles complex, Ontario, the best potential for exploration for additional mineralization may be in the poorly exposed gabbroic-dioritic western part of the pluton.
\end{abstract}

\section{RÉSUMÉ}

Le pluton de Mechanic Settlement, dans le Sud du Nouveau-Brunswick, est un pluton mafique-ultramafique de haut niveau remontant à l'époque du Néoprotérozoïque tardif (environ $557 \mathrm{Ma}$ ). Selon des échantillons de carottes et d'affleurements en surface, le pluton comporte six assemblages lithologiques différents : des assemblages péridotitique, gabbroïque à olivine, gabbrö̈que, anorthositique, troctolitique et dioritique, qui sont constitués d'un éventail de types de roches connexes. Des textures cumulus sont généralement présentes et plusieurs types de roches renferment des silicates hydratés interstitiels, ce qui signale un magma parental humide. La séquence générale de cristallisation minérale à l'intérieur du pluton comprenait de l'olivine et de la chromite, du plagioclase, du clinopyroxène, de l'orthopyroxène et un silicate mafique hydraté (de la phlogopite ou de la hornblende). Les assemblages lithologiques et leurs divers composants ne sont pas présents sous forme continue entre les puits de forage, et les données disponibles n'ont pas pu permettre l'établissement d'une configuration statistiquement déterminante dans la succession stratigraphique. La variation de la composition minéralogique et chimique des roches est régie par la cristallisation fractionnée de l'olivine et du plagioclase. Le pluton de Mechanic Settlement et le basalte du groupe comagmatique de Coldbrook ont probablement une affinité calcoalcaline. Plusieurs horizons renfermant des éléments du groupe du platine associés à une minéralisation modeste de sulfures (pyrrhotite-chalcopyrite-pentlandite) sont présents dans les roches péridotitiques, qui pourraient s'être formées au cours ou à la suite d'un afflux de magma. À en juger d'après les similarités avec le complexe du Lac des îles, en Ontario, la partie occidentale gabbroïque-dioritique faiblement exposée du pluton pourrait offrir le meilleur potentiel pour l'exploration de minéralisations supplémentaires.

[Traduit par la redaction] 


\section{INTRODUCTION}

The mafic and ultramafic Mechanic Settlement Pluton (MSP) is located near the northern margin of the Caledonian Highlands in southern New Brunswick (Fig. 1). The MSP has been a focus of mineral exploration for several decades because it contains sulphide-bearing horizons, some of which exhibit anomalously high platinum-group element (PGE) concentrations (e.g., Ruitenberg et al. 1979; Wells 1992; Warner 1997; Paktunc 2000; Grammatikopoulos et al. 1995, 2007). An understanding of magma evolution is important in evaluating the processes involved in the formation and distribution of sulphide and PGE mineralization in the MSP, and hence in assessing its economic potential. Previous petrological studies of the MSP were based on the limited surface outcrops of the pluton (Grammatikopoulos 1992; Grammatikopoulos et al. 1995) and on a small number of older drill holes (Paktunc 2000). This paper reports the results of a more comprehensive study using core from 20 exploration drill holes, totalling over $5420 \mathrm{~m}$, most of which were not available during earlier work. Although the restricted distribution of the drill holes (Fig. 2) and their limited length (maximum $534 \mathrm{~m}$ ) preclude a comprehensive study, the additional data provide new insights into the threedimensional distribution of rock types in the MSP. Pearce ele- ment ratio analysis of chemical data, including new data from core samples as well as the previously existing database, provide new insight into magma evolution. Comparison with similar plutonic rocks in the Lac des Isles Complex in Ontario suggests additional target areas for mineralization in the MSP.

\section{GEOLOGICAL SETTING}

The Caledonian Highlands are located in Avalonia, an accreted terrane of the northern Appalachian orogen (e.g., Hibbard et al. 2006). Like other parts of Avalonia, the highlands are characterized by Neoproterozoic volcanic rocks, mainly volcanogenic sedimentary rocks, and related plutons (Barr and White 1999). The volcanic and sedimentary rocks have been subdivided into the ca. $620 \mathrm{Ma}$ Broad River Group and the ca. 560-550 Ma Coldbrook Group (Barr et al. 1994; Barr and White 1999). Each of these volcanic packages has a coeval and genetically related suite of intrusive rocks (Barr and White 1999). Similar geochemical signatures, a U-Pb (zircon) age of $557 \pm 3 \mathrm{Ma}$ from a dioritic sample, and ${ }^{40} \mathrm{Ar} /{ }^{39} \mathrm{Ar}$ cooling ages of 550-540 Ma from phlogopite in peridotitic samples indicate that the MSP was comagmatic with basalt in the upper part of the Coldbrook Group (Grammatikopoulos et al. 1995; Barr and White 1999). The host rocks of the MSP are somewhat

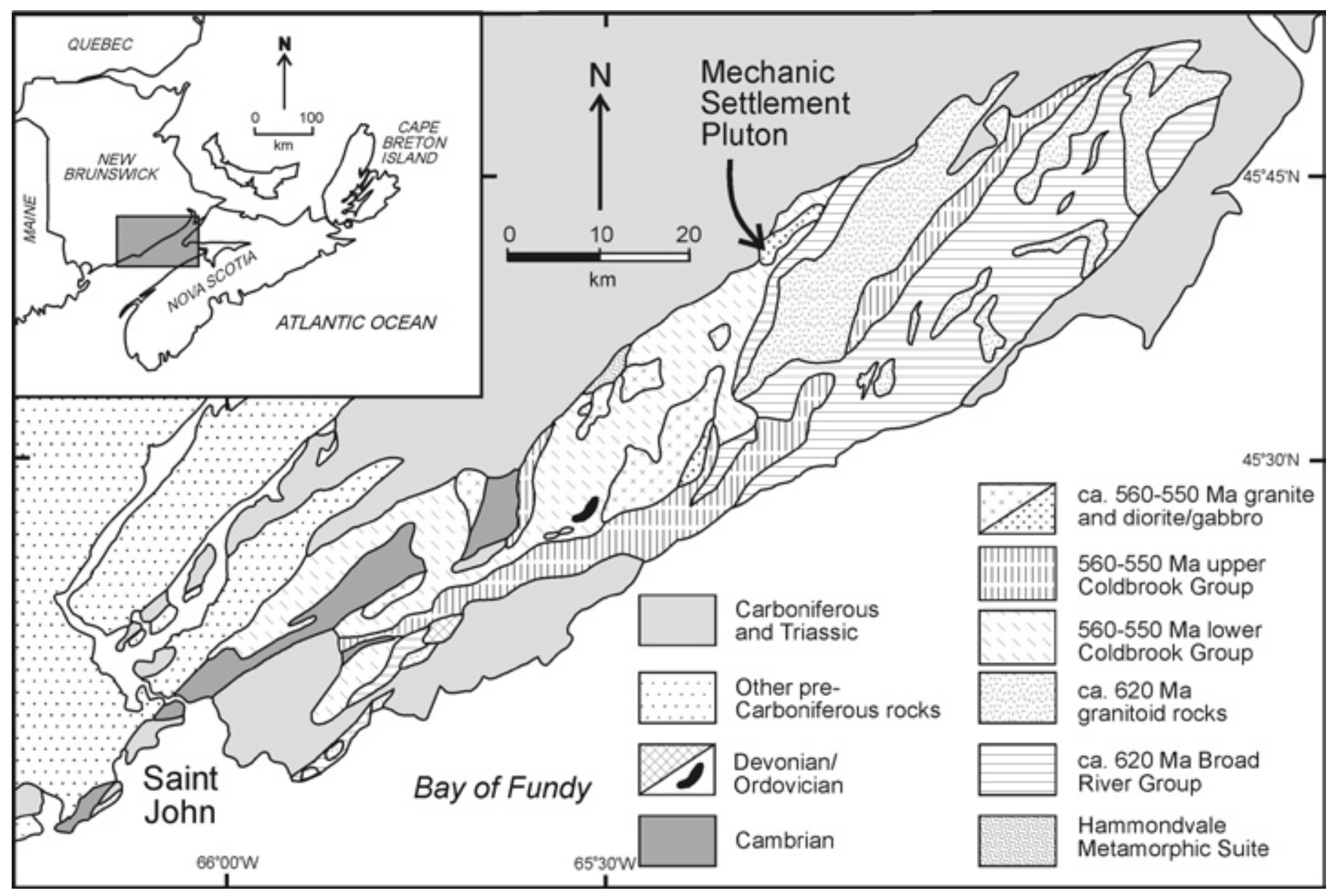

Fig. 1. Simplified geological map of southern New Brunswick, after Barr and White (1999). 
older volcanic and sedimentary rocks of the lower part of the Coldbrook Group (Fig. 2).

The MSP is approximately $2 \mathrm{~km}$ wide and $11 \mathrm{~km}$ long, with several fault-bound outliers to the north and west of the main body (Fig. 2). Composition ranges from peridotite through to diorite, including olivine gabbronorite, troctolite, anorthosite, and gabbro (Grammatikopoulos 1992; Grammatikopoulos et al. 1995; Paktunc 1988, 1989, 2000; Paktunc et al. 1989). Paktunc (2000) identified six variably complete cyclic units consisting of basal peridotite, olivine websterite, olivine gabbronorite, troctolite, gabbroic rocks (gabbro, gabbronorite, or norite), and upper anorthosite. Based on magmatic current structures and modal mineral variations in the cyclic units, Paktunc (2000) concluded that the sill-like intrusion is southfacing, consistent with the younging directions inferred by Barr and White (1999) in host rocks of the lower Coldbrook Group.

\section{METHODS}

For the present study, drill core from the MSP was logged and approximately 50 samples from the core were studied in thin section. These data were used in combination with surface samples archived at Acadia University in the thesis collection of Grammatikopoulos (1992) to further characterize the lithologies in the MSP. Correlation between drill holes was investigated using both core logs and magnetic-susceptibility data measured at $1 \mathrm{~m}$ intervals in the drill core using a Exploranium KT-9 Kappameter (data in Hiebert 2005).

In addition to petrographic study, 93 samples were selected for chemical analysis, including 67 from drill core and 26 from surface samples. Samples selected from the surface sample collection of Grammatikopoulos (1992) were included, as well as pulps in the archives of the New Brunswick Department of Natural Resources (Sussex) from the drill core collection of Warner (1997). Eight aliquots of a basalt reference sample were included to assess accuracy and precision (see Appendix E in Hiebert 2005). Chemical analyses were done at the Regional Geochemical Centre, Saint Mary's University, Halifax. Major elements and V, Cr, Ba, Ni, Zn, Ga, Sr, Zr, and Nb, were measured on a Philips PW2400 X-ray spectrometer using fused sample disks. Elements $\mathrm{Co}, \mathrm{Cu}, \mathrm{Rb}, \mathrm{Y}, \mathrm{La}, \mathrm{Nd}$, Th, and U were analyzed on the same machine using pressed powder pellets. The chemical database and analytical methods are described in more detail in Hiebert (2005).

\section{LITHOLOGIES IN THE MECHANIC SETTLEMENT PLUTON}

Eighteen rock types were recognized in the MSP during this study, based on visual estimates of modal mineralogy and the classification of Streckeisen (1976) for mafic and ultramafic plutonic rocks. The rock types are grouped into 6 lithologic assemblages, as summarized in Table 1 and illustrated in terms

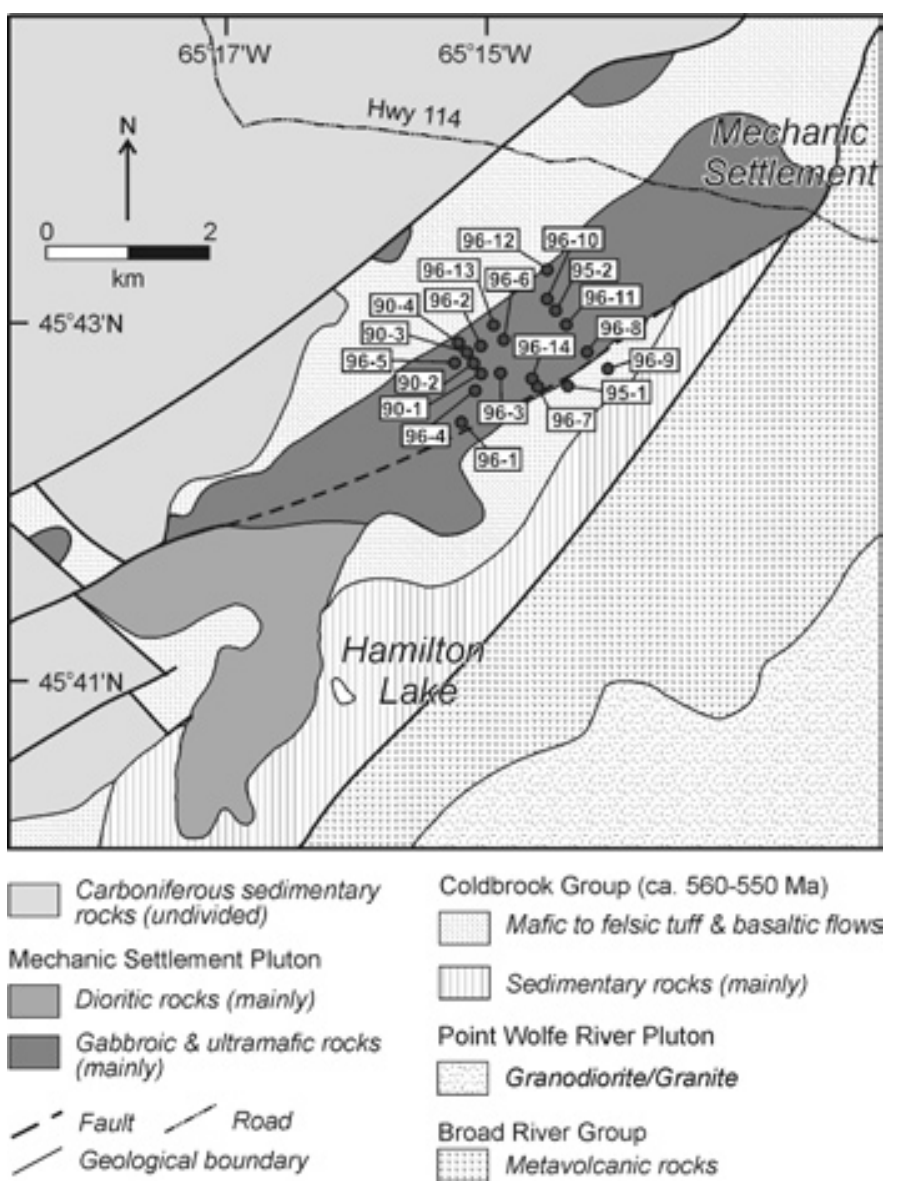

Fig. 2. Simplified geological map of the Mechanic Settlement Pluton, after Grammatikopoulos et al. (1995) and Barr and White (2004). Drill hole locations are shown.

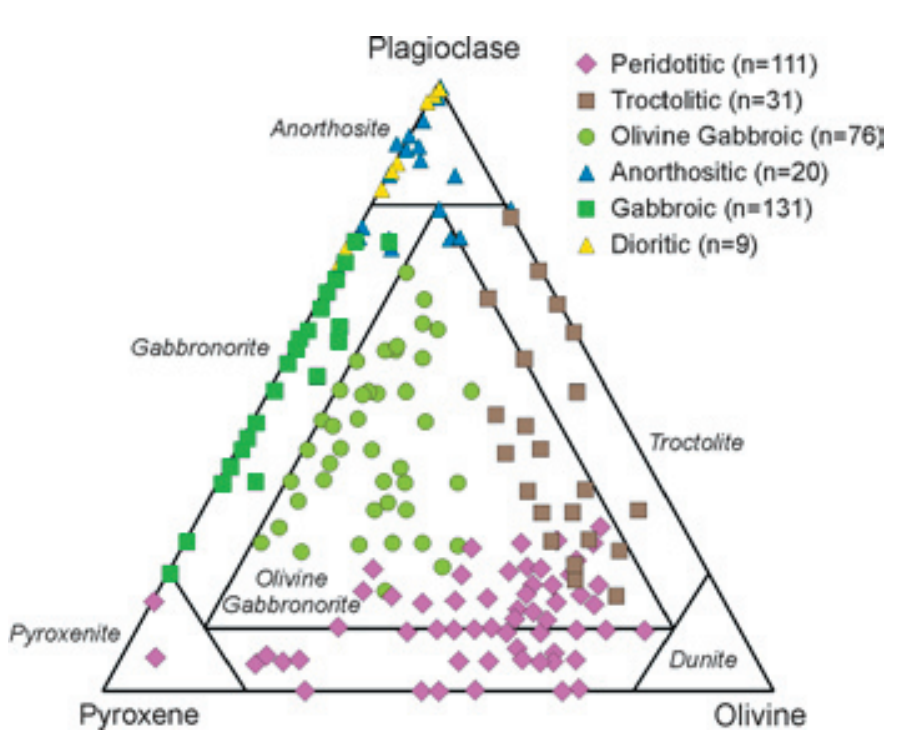

Fig. 3. Diagram showing the modal mineralogical variation within lithologic assemblages in the MSP. Fields are after Streckeisen (1976). 
of modal plagioclase, pyroxene, and olivine in Figure 3. More detailed documentation of the gradational modal variations within the six lithological assemblages was presented by Hiebert (2005). Based on drill-hole data, all from the north-central part of the MSP (Fig. 2), peridotitic rocks dominate, although olivine-bearing gabbroic, gabbroic, and troctolitic rocks are also common, whereas anorthositic rocks are rare, and dioritic rocks occur only as thin bands in the drill core. Outcrop is not sufficient to map the distribution of rock types in any detail at surface; however, peridotitic rocks are abundant along the northern and southern margins of the MSP, and gabbroic rocks (including olivine-bearing gabbroic and troctolitic rocks) near the middle. Anorthositic and dioritic rocks are minor, except in the southwestern part of the MSP, which is dominated by dioritic rocks (Fig. 2). Petrographic characteristics of the rock types are summarized in Table 1, and examples are shown in photomicrographs in Figure 4. Significant variations in grain size occur only in the gabbroic rocks.

Contacts between rock types within each lithologic assemblage were observed mainly in drill core and tend to be gradational on a metre scale, whereas contacts between lithological assemblages in places are gradational over a distance of a few metres or centimetres, but in other places are sharp, or even intrusive. Thin bands of diorite seen in drill core appear to have intrusive contacts, suggesting that they formed later than the surrounding rocks. However, no chilled margins were observed, suggesting that the diorite formed during a later magmatic injection while the rest of the pluton was still relatively hot. This later magma injection may have produced the larger dioritic body that forms much of the southwestern part of the MSP. In the poorly exposed northwestern part of the pluton, complex magma-mingling relationships appear to exist between dioritic and gabbroic rocks, where medium- to coarse-grained and pegmatitic dioritic rocks intruded finegrained gabbroic rocks. The contacts between the units are irregular where exposed.

Outcrops of host rocks of the Coldbrook Group north of the MSP are hornfelsed, but contacts with the MSP are not exposed at surface. However, a contact was observed in drill core (hole MS-96-12) that is marked by a marginal zone consisting of alternating masses of intrusive and host rocks, suggesting the existence of abundant xenoliths at the margin of the pluton. The plutonic rocks near the contact are fine- to medium-grained olivine gabbroic rocks, which are highly altered to secondary serpentine, hematite, and epidote. Abundant serpentinite and epidosite veins indicate interaction with fluids. Locally on the other margins, the MSP is in faulted contact with the host rocks (Fig. 2). A fault through the MSP and along part of its southern margin is suggested by a lack of evidence for contact metamorphic effects in drill core (e.g., MS96-9). Other shear zones were also noted in drill core, characterized by intense hydrothermal alteration and abrupt changes in lithology.

Plagioclase in peridotitic samples, if present, forms small $(<$ 1-2 mm), equidimensional interstitial, but subhedral, grains. The subhedral shape suggests that plagioclase was not formed from interstitial liquid late in the crystallization sequence, but also crystallized early. In places, plagioclase is intergrown with clinopyroxene (e.g., Fig. 4a), indicating that the two minerals crystallized at the same time, whereas in other samples it is enclosed by large poikilitic pyroxene, indicating that plagioclase crystallized earlier. Rarely, very small plagioclase crystals are enclosed by olivine, showing that some plagioclase crystallized before at least some of the olivine. Primary opaque oxide minerals are chromite in peridotitic rocks and magnetite in other lithologic assemblages. The overall interpreted crystallization sequence of all rocks in the MSP is olivine + chromite, olivine + plagioclase \pm chromite (or olivine + clinopyroxene + chromite in olivine websterite), olivine + plagioclase + clinopyroxene, plagioclase + clinopyroxene \pm orthopyroxene, clinopyroxene \pm orthopyroxene, and finally hornblende or phlogopite (Table 1).

Crystallization of the MSP was followed by hydrous alteration, first changing pyroxene to amphibole and biotite, probably at high temperature, and subsequently introducing lower temperature secondary minerals including serpentine, chlorite, and epidote. Overall, alteration of primary igneous minerals is relatively minor throughout the MSP, and strong alteration is restricted to discrete zones, associated with shearing or minor faults.

On average, magnetic susceptibility is highest in olivinebearing lithologies (peridotitic, olivine-bearing gabbroic, and troctolitic) and lowest in gabbroic rocks, with anorthositic and dioritic rocks generally having intermediate susceptibilities (Table 1). Susceptibility is controlled in part by the alteration of olivine and pyroxene to serpentine/epidote and magnetite, and hence the data tend to be highly variable even in one rock type (Fig. 5). Sulphide-bearing horizons do not have significantly higher susceptibilities than the surrounding rocks.

\section{IGNEOUS LAYERING}

Variations in modal mineralogy are characteristic of the MSP, and small-scale layering is seen in some outcrops and in sections of the drill core. Grammatikopoulos et al. (1995) reported layering striking northeast and dipping steeply south to southwest in rare outcrops. However, on a larger scale, it is difficult to trace specific rock types between drill holes. For example, lithologic and magnetic susceptibility logs for six holes along a north-south section across the intrusion do not reveal clear matches (Fig. 5). Hence if large-scale layering exists in the MSP, it is either discontinuous and/or disrupted by unrecognized faults.

To search for systematic lithological variations in the MSP, Markov Chain Analysis was used. This technique is useful for investigating a sequence of events in which the probability of each event depends on the previous event (Ross 2000). In the MSP, for example, such a sequence could be the crystallization of olivine-bearing gabbroic rocks following crystallization of peridotitic rocks due to fractionation of the magma. The analysis was done by calculating the percentage of times that each petrologic assemblage is in contact with each of the other pet- 
Table 1. Characteristics of the six lithologic assemblages in the MSP, summarized from Hiebert (2005).

\begin{tabular}{|c|c|c|c|c|c|c|}
\hline $\begin{array}{l}\text { Lithologic } \\
\text { Assemblage }\end{array}$ & Peridotitic & $\begin{array}{l}\text { Olivine-bearing } \\
\text { Gabbroic }\end{array}$ & Gabbroic & Anorthositic & Troctolitic & Dioritic \\
\hline $\begin{array}{l}\text { Lithologies } \\
\text { Included (rock } \\
\text { names after } \\
\text { Streckeisen 1976). }\end{array}$ & $\begin{array}{l}\text { olivine-rich } \\
\text { lherzolite, } \\
\text { lherzolite, } \\
\text { olivine } \\
\text { websterite, } \\
\text { plagioclase } \\
\text { lherzolite, } \\
\text { olivine } \\
\text { plagioclase } \\
\text { lherzolite }\end{array}$ & $\begin{array}{c}\text { olivine gabbro, } \\
\text { olivine } \\
\text { gabbronorite }\end{array}$ & $\begin{array}{l}\text { gabbronorite, } \\
\text { gabbro, } \\
\text { hornblende } \\
\text { gabbro }\end{array}$ & $\begin{array}{c}\text { anorthosite, } \\
\text { anorthositic } \\
\text { gabbro, } \\
\text { anorthositic } \\
\text { troctolite }\end{array}$ & $\begin{array}{l}\text { troctolite, } \\
\text { troctolitic olivine } \\
\text { gabbronorite }\end{array}$ & $\begin{array}{l}\text { diorite, quartz } \\
\text { diorite }\end{array}$ \\
\hline Minerals Present & $\begin{array}{l}\text { olivine, } \\
\text { clinopyroxene, } \\
\text { plagioclase, } \\
\text { orthopyroxene, } \\
\text { chromite, } \\
\text { phlogopite }\end{array}$ & $\begin{array}{c}\text { olivine, } \\
\text { clinopyroxene, } \\
\text { plagioclase, } \\
\text { orthopyroxene, } \\
\text { and magnetite }\end{array}$ & $\begin{array}{c}\text { olivine, } \\
\text { clinopyroxene, } \\
\text { plagioclase, } \\
\text { orthopyroxene, } \\
\text { and magnetite, } \\
\text { +/- hornblende }\end{array}$ & $\begin{array}{c}\text { plagioclase } \\
\text { (minor olivine, } \\
\text { clinopyroxene, } \\
\text { and/or } \\
\text { hornblende) }\end{array}$ & $\begin{array}{c}\text { olivine, } \\
\text { plagioclase } \\
\text { (minor } \\
\text { clinopyroxene } \\
\text { and } \\
\text { orthopyroxene) }\end{array}$ & $\begin{array}{l}\text { plagioclase, } \\
\text { hornblende, } \\
\pm \text { quartz }\end{array}$ \\
\hline $\begin{array}{l}\text { Cumulate } \\
\text { Texture }\end{array}$ & $\begin{array}{c}\text { orthocumulate } \\
\text { or } \\
\text { mesocumulate } \\
\text { (except olivine } \\
\text { websterite: } \\
\text { adcumulate) } \\
\end{array}$ & mesocumulate & $\mathrm{n} / \mathrm{a}$ & adcumulate & adcumulate & $\mathrm{n} / \mathrm{a}$ \\
\hline $\begin{array}{l}\text { Cumulate } \\
\text { Minerals }\end{array}$ & $\begin{array}{c}\text { olivine }(+ \\
\text { chromite) } \\
\text { (olivine } \\
\text { websterite: } \\
\text { olivine + } \\
\text { clinopyroxene + } \\
\text { chromite) } \\
\end{array}$ & $\begin{array}{c}\text { olivine + } \\
\text { plagioclase }\end{array}$ & $\mathrm{n} / \mathrm{a}$ & $\begin{array}{c}\text { plagioclase }(+ \\
\text { olivine where } \\
\text { present) }\end{array}$ & $\begin{array}{c}\text { olivine + } \\
\text { plagioclase }\end{array}$ & $\mathrm{n} / \mathrm{a}$ \\
\hline $\begin{array}{l}\text { Grain Size \& } \\
\text { Phenocrysts }\end{array}$ & medium grained & $\begin{array}{l}\text { medium to } \\
\text { coarse grained, } \\
\text { or fine grained } \\
\text { with olivine } \\
\text { phenocrysts }\end{array}$ & $\begin{array}{c}\text { medium to } \\
\text { coarse grained, } \\
\text { or fine grained }\end{array}$ & coarse grained & $\begin{array}{c}\text { medium to } \\
\text { coarse grained, } \\
\text { with poikilitic } \\
\text { clinopyroxene } \\
\text { and } \\
\text { orthopyroxene }\end{array}$ & $\begin{array}{c}\text { medium to coarse } \\
\text { grained anhedral } \\
\text { plagioclase, fine } \\
\text { grained anhedral } \\
\text { matrix }\end{array}$ \\
\hline $\begin{array}{l}\text { Crystallization } \\
\text { Sequence }\end{array}$ & $\begin{array}{c}\text { olivine + } \\
\text { chromite, olivine } \\
\text { + plagioclase } \pm \\
\text { chromite, olivine } \\
\text { + plagioclase + } \\
\text { clinopyroxene, } \\
\text { clinopyroxene + } \\
\text { orthopyroxene, } \\
\text { phlogopite }\end{array}$ & $\begin{array}{l}\text { olivine, olivine + } \\
\text { plagioclase, } \\
\text { plagioclase }+ \\
\text { clinopyroxene } \pm \\
\text { orthopyroxene, } \\
\text { clinopyroxene } \pm \\
\text { orthopyroxene }\end{array}$ & $\begin{array}{c}\text { plagioclase, } \\
\text { plagioclase }+ \\
\text { clinopyroxene } \pm \\
\text { orthopyroxene, } \\
\text { clinopyroxene } \pm \\
\text { orthopyroxene, } \\
\text { hornblende } \\
\text { (where present) }\end{array}$ & $\begin{array}{c}\text { plagioclase } \pm \\
\text { olivine, } \\
\text { plagioclase } \pm \\
\text { clinopyroxene, } \\
\text { hornblende } \\
\text { (where present) }\end{array}$ & $\begin{array}{l}\text { olivine, olivine + } \\
\text { plagioclase, } \\
\text { clinopyroxene + } \\
\text { orthopyroxene } \\
\text { (where present) }\end{array}$ & $\begin{array}{c}\text { plagioclase, } \\
\text { plagioclase }+ \\
\text { hornblende } \pm \\
\text { quartz }\end{array}$ \\
\hline $\begin{array}{c}\text { Olivine } \\
\text { Chemistry }\end{array}$ & $\begin{array}{c}\mathrm{Fo}_{83-80} \\
\text { (36 samples) }\end{array}$ & $\mathrm{Fo}_{77}(1$ sample $)$ & $\mathrm{n} / \mathrm{a}$ & $\mathrm{Fo}_{83}$ (3 samples) & $\begin{array}{c}\mathrm{Fo}_{77-76} \\
\text { (5 samples) }\end{array}$ & $\mathrm{n} / \mathrm{a}$ \\
\hline $\begin{array}{l}\text { Plagioclase } \\
\text { Chemistry }\end{array}$ & $\begin{array}{l}\text { bimodal } \mathrm{An}_{90-83} \\
\text { and } \mathrm{An}_{69-55} \\
\text { (11 analyses) }\end{array}$ & $\begin{array}{l}{\text { bimodal } \mathrm{An}_{84-80}} \\
\mathrm{An}_{76} \text { (4 analyses) }\end{array}$ & $\begin{array}{c}\mathrm{An}_{67-47} \\
\text { (21 analyses) }\end{array}$ & $\begin{array}{c}\mathrm{An}_{87-86} \\
\text { (4 analyses) }\end{array}$ & $\begin{array}{c}\mathrm{An}_{89-84} \\
\text { (5 analyses) }\end{array}$ & $\mathrm{n} / \mathrm{a}$ \\
\hline $\begin{array}{l}\text { Clinopyroxene } \\
\text { Chemistry }\end{array}$ & $\begin{array}{c}\mathrm{Mg}{ }_{87-78} \\
\text { average } \mathrm{Mg}_{85}\end{array}$ & $\begin{array}{c}\mathrm{Mg \#}_{84-80} \\
\text { (8 samples) }\end{array}$ & $\begin{array}{l}\mathrm{Mg \#}_{64-63} \\
\text { (9 samples) }\end{array}$ & $\begin{array}{c}\mathrm{Mg \#}_{87-86} \\
\text { (3 samples) }\end{array}$ & $\begin{array}{c}\mathrm{Mg}_{86-81}, \text { average } \\
\text { Mg\# }_{84} \\
\text { (3 samples) } \\
\end{array}$ & $\mathrm{n} / \mathrm{a}$ \\
\hline $\begin{array}{l}\text { Orthopyroxene } \\
\text { Chemistry }\end{array}$ & $\mathrm{En}_{83-80}$ & $\begin{array}{c}\text { En }_{77-76} \\
\text { (3 samples) }\end{array}$ & $\begin{array}{c}\mathrm{En}_{55-54} \\
\text { (2 samples) }\end{array}$ & $\mathrm{n} / \mathrm{a}$ & $\mathrm{n} / \mathrm{a}$ & $\mathrm{n} / \mathrm{a}$ \\
\hline $\begin{array}{c}\text { Average k } \\
\text { in Drill Core }\end{array}$ & $\begin{array}{c}57 \times 10^{-3} \mathrm{SI} \\
(\mathrm{n}=2656)\end{array}$ & $\begin{array}{c}65 \times 10^{-3} \mathrm{SI} \\
(\mathrm{n}=1386)\end{array}$ & $\begin{array}{c}17 \times 10^{-3} \mathrm{SI} \\
(\mathrm{n}=1413)\end{array}$ & $\begin{array}{c}31 \times 10^{-3} \mathrm{SI} \\
(\mathrm{n}=47)\end{array}$ & $\begin{array}{c}109 \times 10^{-3} \mathrm{~S} \\
(\mathrm{n}=250)\end{array}$ & $\begin{array}{c}48 \times 10^{-3} \mathrm{SI} \\
(\mathrm{n}=8)\end{array}$ \\
\hline
\end{tabular}


rologic assemblages (Table 2). The results show no consistent associations as might be expected if crystal fractionation were the sole process involved in magma evolution. For example, peridotitic rocks occur below olivine gabbroic and gabbroic rocks almost equally often (39\% and $46 \%$ of contacts, respectively), and olivine gabbroic rocks occur below peridotitic and gabbroic rocks almost equally often $(42 \%$ and $37 \%$ of contacts, respectively). However, $60 \%$ of upper contacts of gabbroic rocks are
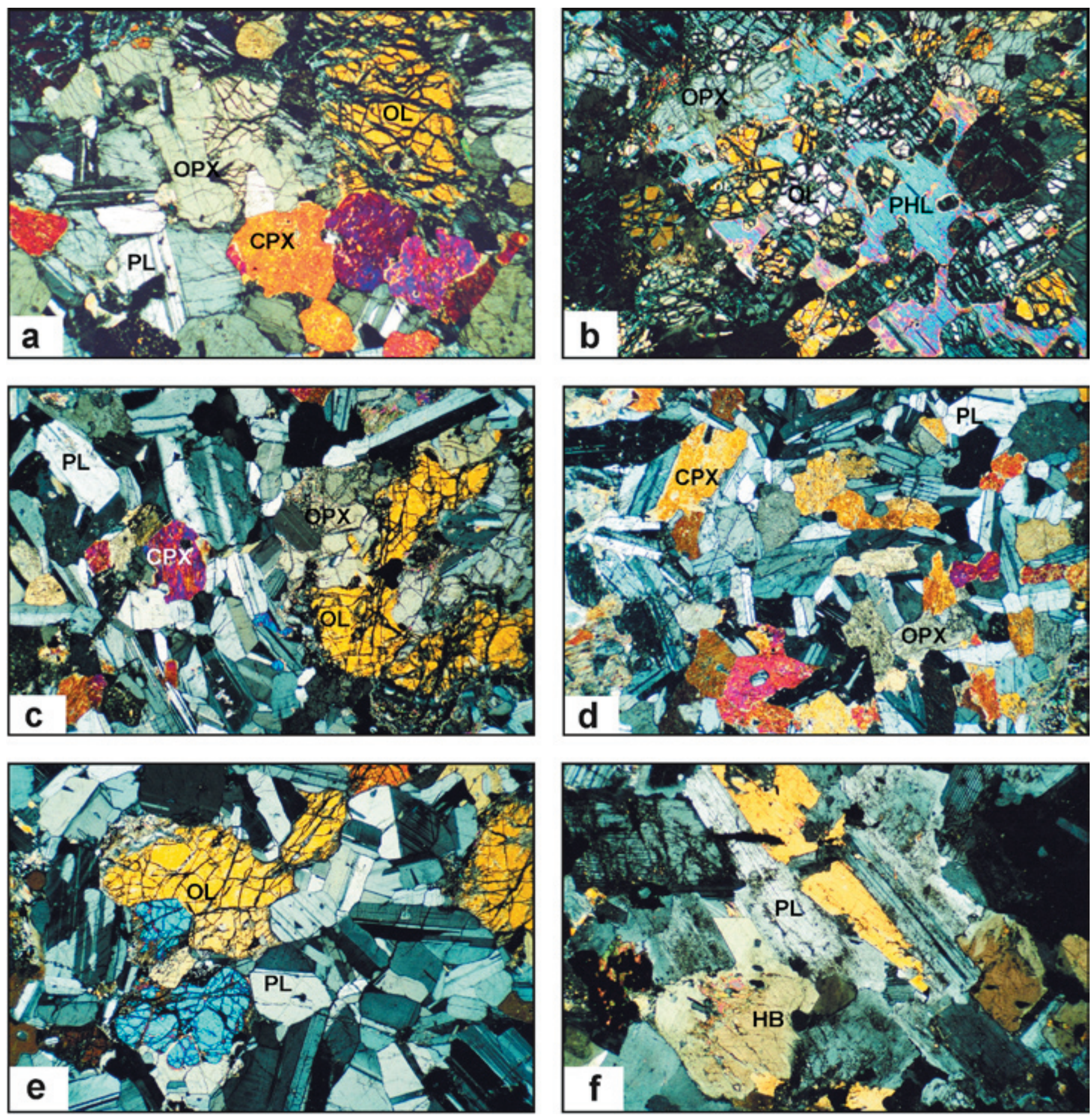

Fig. 4. Photomicrographs showing examples of lithologies in the MSP. (a) Plagioclase-bearing lherzolite (sample RH0364). (b) Olivine websterite with phlogopite (sample RH03-84). (c) olivine gabbronorite (sample RH03-57). (d) Mediumgrained gabbronorite (sample RH03-57). (e) Troctolite (sample RH03-100). (f) Diorite (sample MS-230). All photographs are under crossed polars. Width of field of view is $4 \mathrm{~mm}$. Symbols: CPX, clinopyroxene; HB, hornblende; PL, plagioclase; OL, olivine; OPX, orthopyroxene; PHL, phlogopite. 
$\frac{5}{2}$

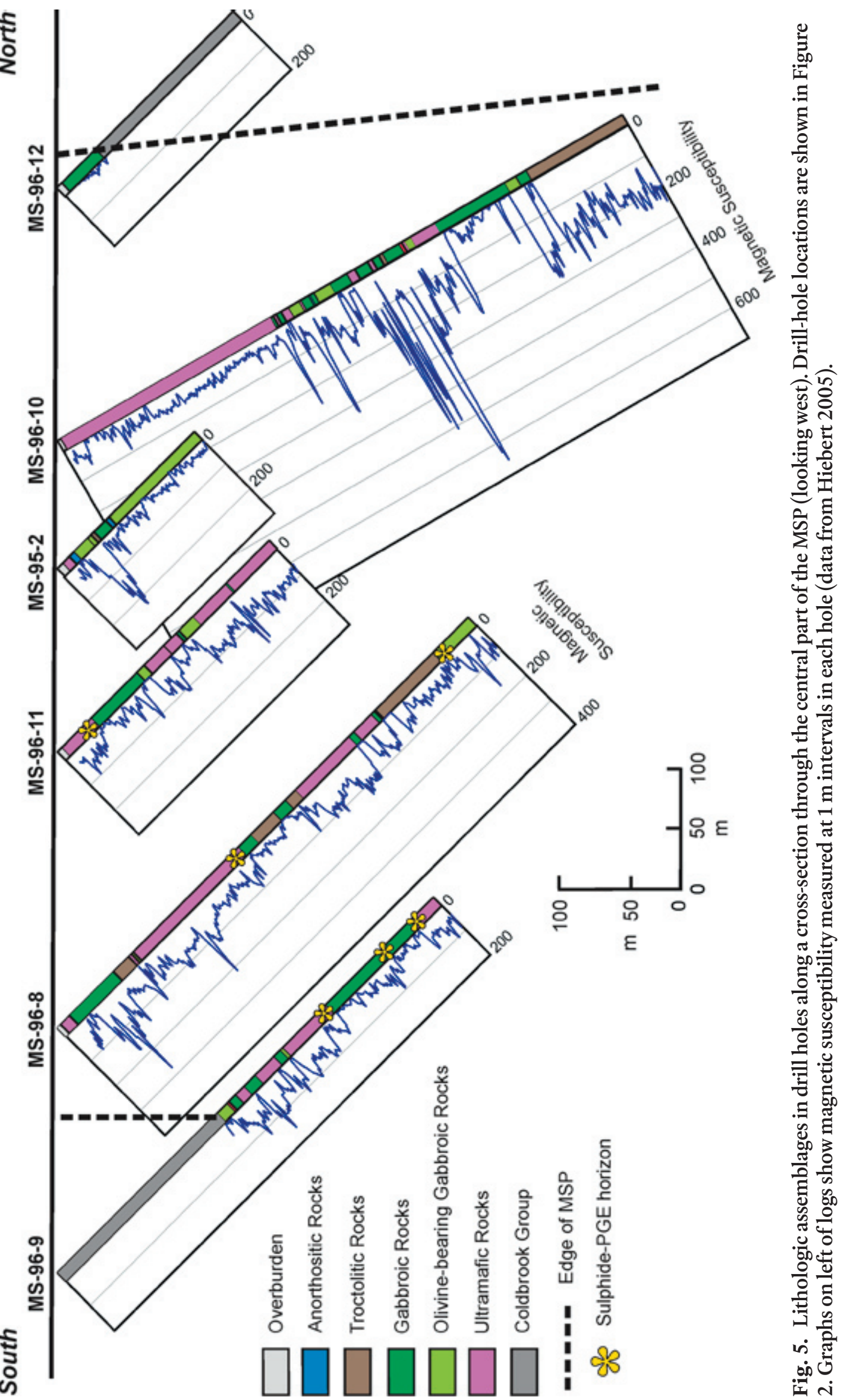


Table 2. Results of Markov Chain Analysis for the MSP using all contacts. Upper part of the table shows total number of times each petrologic assemblage occurs above another. Lower part of the table shows the same data as a percentage of total transitions. In both tables, rows indicate petrologic assemblage below and columns indicate petrologic assemblage above each contact.

\begin{tabular}{|c|c|c|c|c|c|c|c|}
\hline Counts & Peridotitic & $\begin{array}{l}\text { Olivine } \\
\text { Gabbroic }\end{array}$ & Gabbroic & Troctolitic & Anorthositic & Dioritic & Total \\
\hline Peridotitic & 0 & 31 & 37 & 3 & 7 & 2 & 80 \\
\hline $\begin{array}{l}\text { Olivine } \\
\text { Gabbroic }\end{array}$ & 25 & 0 & 22 & 7 & 5 & 0 & 59 \\
\hline Gabbroic & 46 & 8 & 0 & 14 & 5 & 4 & 77 \\
\hline Troctolitic & 2 & 9 & 14 & 0 & 1 & 0 & 26 \\
\hline Anorthositic & 6 & 6 & 4 & 1 & 0 & 0 & 17 \\
\hline Dioritic & 2 & 1 & 3 & 0 & 0 & 0 & 6 \\
\hline Percentage & Peridotitic & $\begin{array}{l}\text { Olivine } \\
\text { Gabbroic }\end{array}$ & Gabbroic & Troctolitic & Anorthositic & Dioritic & \\
\hline Peridotitic & $\begin{array}{r}0 \\
\end{array}$ & $\begin{array}{r}39 \\
\end{array}$ & 46 & 4 & 9 & 3 & 100 \\
\hline $\begin{array}{l}\text { Olivine } \\
\text { Gabbroic }\end{array}$ & 42 & 0 & 37 & 12 & 8 & 0 & 100 \\
\hline Gabbroic & 60 & 10 & 0 & 18 & 6 & 5 & 100 \\
\hline Troctolitic & 8 & 35 & 54 & 0 & 4 & 0 & 100 \\
\hline Anorthositic & 35 & 35 & 24 & 6 & 0 & 0 & 100 \\
\hline Dioritic & 33 & 17 & 50 & 0 & 0 & 0 & 100 \\
\hline
\end{tabular}

Table 3. Results of Markov Chain Analysis for the MSP using only gradational contacts. Upper part of the table shows total number of times each petrologic assemblage occurs above another. Lower part of the table shows the same data as a percentage of total transitions. In both tables, rows indicate petrologic assemblage below and columns indicate petrologic assemblage above each contact.

\begin{tabular}{|c|c|c|c|c|c|c|c|}
\hline Counts & Peridotitic & \begin{tabular}{|l} 
Olivine \\
Gabbroic
\end{tabular} & Gabbroic & Troctolitic & Anorthositic & Dioritic & Total \\
\hline Peridotitic & 0 & 11 & 10 & 0 & 2 & 0 & 23 \\
\hline $\begin{array}{l}\text { Olivine } \\
\text { Gabbroic }\end{array}$ & 23 & 0 & 23 & 3 & 4 & 0 & 53 \\
\hline Gabbroic & 11 & 3 & 0 & 7 & 3 & 0 & 24 \\
\hline Troctolitic & 1 & 7 & 5 & 0 & 0 & 0 & 13 \\
\hline Anorthositic & 3 & 3 & 3 & 0 & 0 & 0 & 9 \\
\hline Dioritic & 0 & 0 & 0 & 0 & 0 & 0 & 0 \\
\hline Percentage & Peridotitic & \begin{tabular}{|l|} 
Olivine \\
Gabbroic
\end{tabular} & Gabbroic & Troctolitic & Anorthositic & Dioritic & \\
\hline Peridotitic & 0 & 48 & 43 & 0 & 9 & & 100 \\
\hline \begin{tabular}{|l} 
Olivine \\
Gabbroic \\
\end{tabular} & 43 & 0 & 43 & 6 & 8 & & 100 \\
\hline Gabbroic & 46 & 13 & 0 & 29 & 13 & & 100 \\
\hline Troctolitic & 8 & 54 & 38 & 0 & 0 & & 100 \\
\hline Anorthositic & 33 & 33 & 33 & 0 & 0 & & 100 \\
\hline Dioritic & 0 & 0 & 0 & 0 & 0 & & 100 \\
\hline
\end{tabular}


ATLANTIC GEOLOGY $\cdot$ VOLUME $44 \cdot 2008$

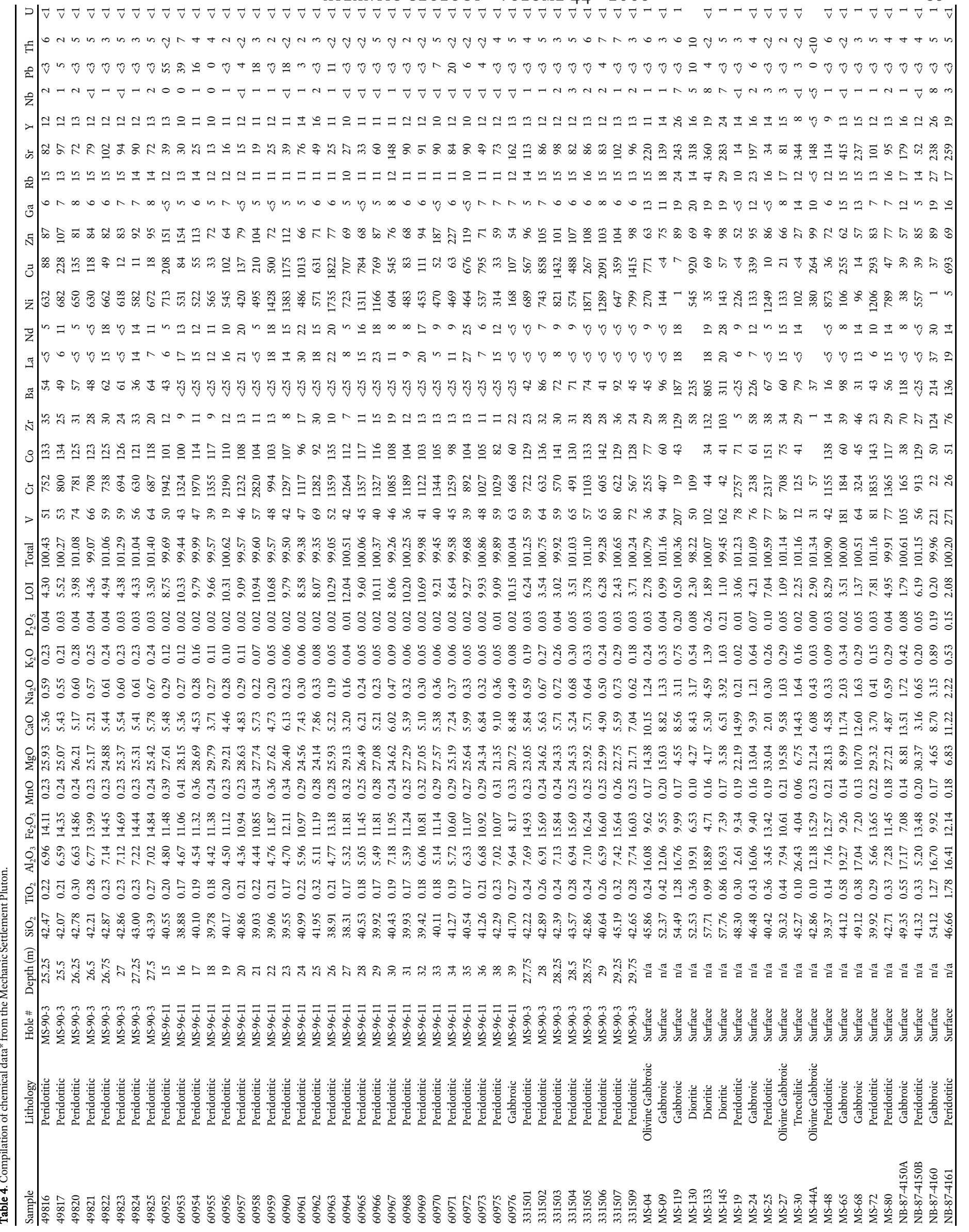




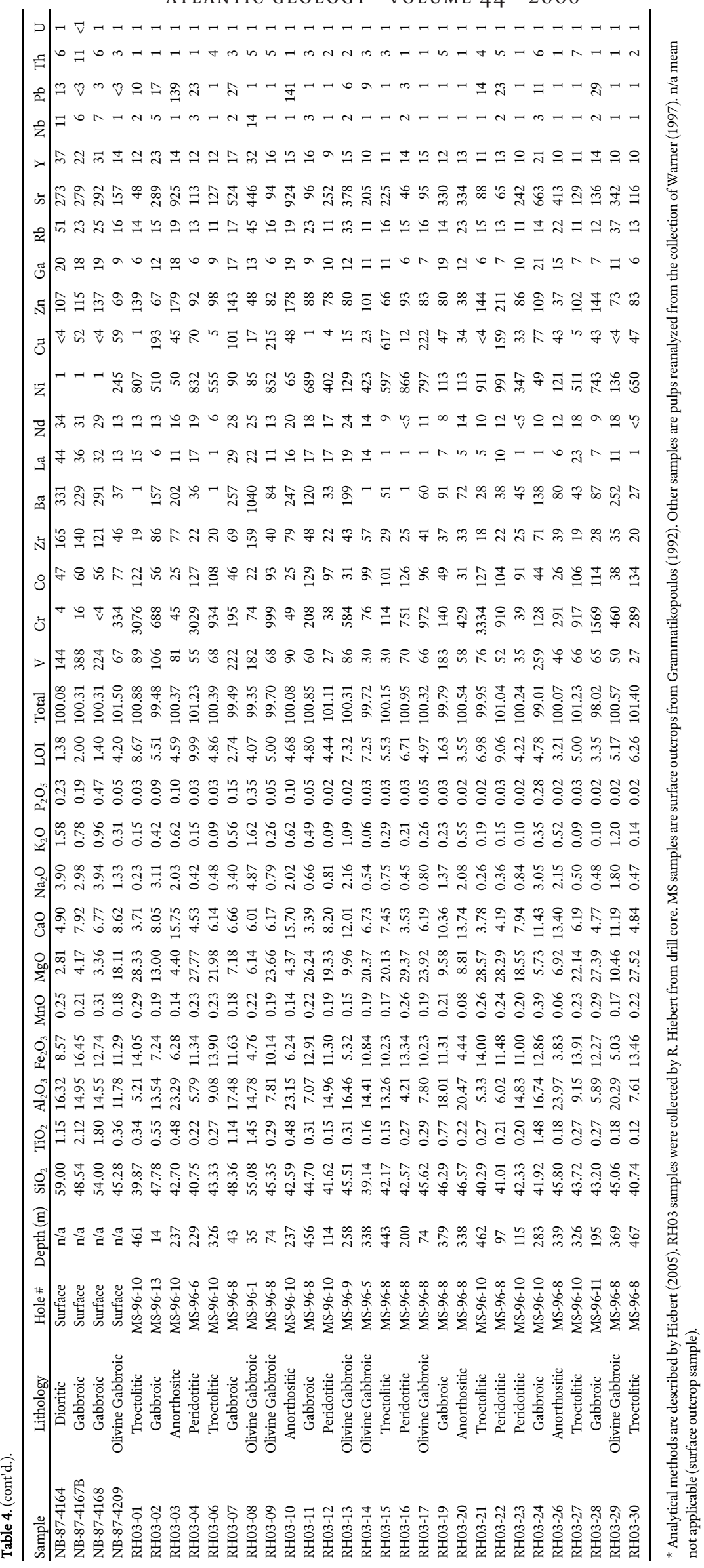


with peridotite, and $54 \%$ of contacts above troctolitic rocks are with gabbroic rocks.

In order to ensure that intrusive, faulted, and erosional contacts were not hiding systematic variations, a separate analysis was done, using only contacts that are gradational (Table 3). The results show some differences from the calculation using all contact types; for example, gabbroic rocks occur below peridotitic and troctolitic rocks $46 \%$ and $29 \%$ of their gradational contacts, whereas the corresponding figures were $60 \%$ and $18 \%$ when all contacts were used (Table 2 ). However,

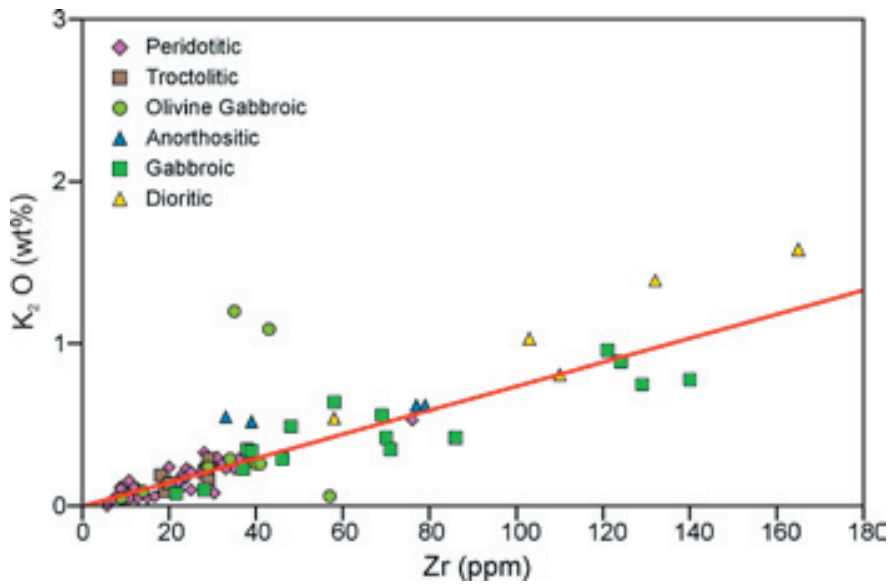

Fig. 6. Plot of $\mathrm{K}_{2} \mathrm{O}$ against $\mathrm{Zr}$. The MSP samples tend to lie on a trend line through the origin, consistent with both elements being conserved.

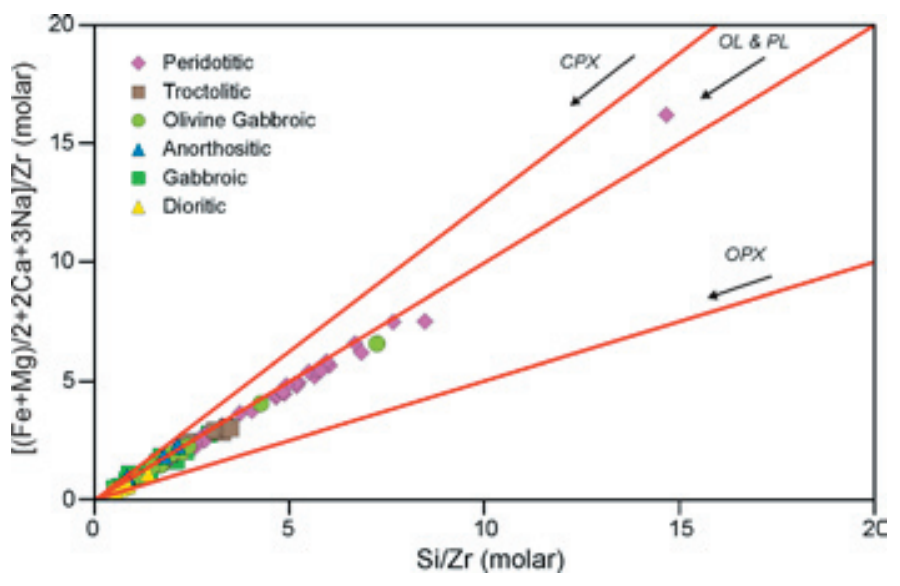

Fig. 8. Plot of molar amounts of $[(\mathrm{Fe}+\mathrm{Mg}) / 2+2 \mathrm{Ca}+$ $3 \mathrm{Na})] / \mathrm{Zr}$ against $\mathrm{Si} / \mathrm{Zr}$. The trend in the data coincides with that expected from olivine and plagioclase fractionation (middle line), with little influence by orthopyroxene (lower line) or clinopyroxene (upper line) removal. still no consistent succession of lithologies was identified to suggest widespread repetitive layering or cyclicity in rock type distribution, at least in the part of the pluton represented by the drill core.

\section{GEOCHEMISTRY}

Geochemical variation in the MSP was described by Grammatikopoulos (1992), Grammatikopoulos et al. (1995),

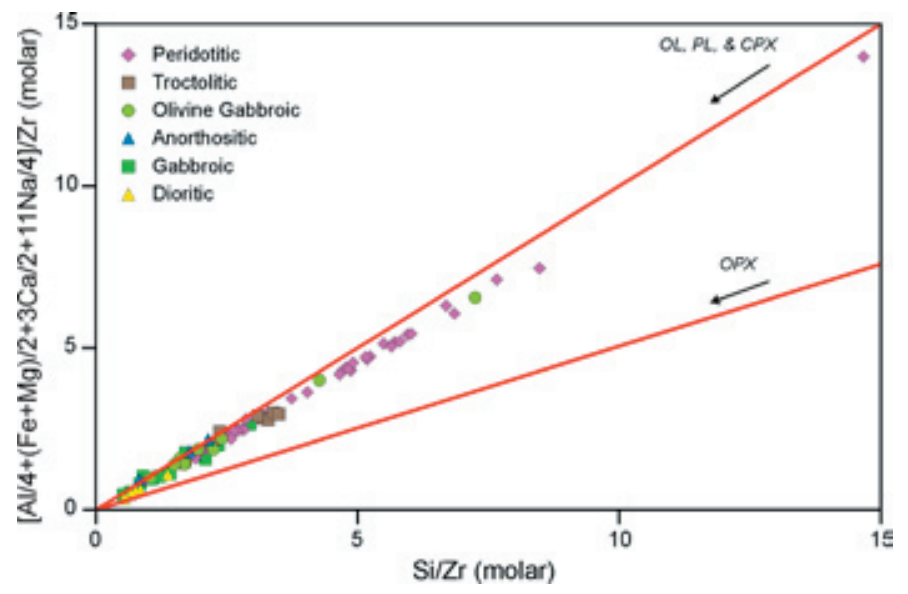

Fig. 7. Plot of molar amounts of $[\mathrm{Al} / 4+(\mathrm{Fe}+\mathrm{Mg}) / 2+3 \mathrm{Ca} / 2$ $+11 \mathrm{Na} / 4] / \mathrm{Zr}$ against $\mathrm{Si} / \mathrm{Zr}$. The samples plot along or near the trend line for fractionation of the mineral assemblage olivine, plagioclase, and clinopyroxene (upper line). The slight downward shift in the data suggests that orthopyroxene fractionation (lower line) played a minor role in the process.

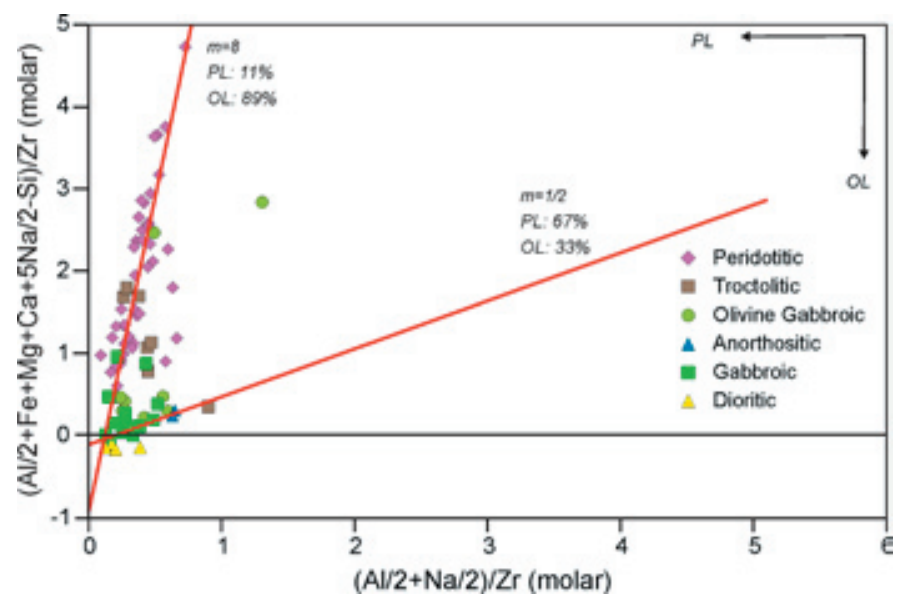

Fig. 9. Plot of molar amounts of $(\mathrm{Al} / 2+\mathrm{Fe}+\mathrm{Mg}+\mathrm{Ca}+$ $5 \mathrm{Na} / 2-\mathrm{Si}) / \mathrm{Zr}$ against $(\mathrm{Al} / 2+\mathrm{Na} / 2) / \mathrm{Zr}$ to investigate the relative proportions of olivine and plagioclase during crystal fractionation. The line with slope of 8 indicates the trend in peridotitic rocks, corresponding to $89 \%$ olivine and $11 \%$ plagioclase fractionation. The weak, shallower trend in the other rock types indicates greater plagioclase control. 
and Paktunc (2000), using a relatively small number of samples. The results of these studies qualitatively suggested that magma evolution was controlled by olivine and plagioclase fractionation. To more quantitatively characterize chemical variation and magma evolution, the larger chemical data base, including samples analyzed in the present study (Table 4) was examined using Pearce element ratio (PER) diagrams (Pearce 1968; Stanley and Russell 1989; Stanley 1998). PER diagrams avoid the effects of closure, and can describe the actual material transfers of the major elements. PER analysis requires identification of a conserved element; that is, an incompatible element that did not participate in material transfer (Pearce 1968; Stanley and Russell 1989). In the MSP dataset, the trend on a scatter plot of $\mathrm{Zr}$ vs. $\mathrm{K}_{2} \mathrm{O}$ passes through the origin (Fig. 6), thus suggesting that both of these elements are conserved. However, $\mathrm{Zr}$ was chosen as the conserved element in the PER diagrams because of its lower partition coefficient into the primary phases (olivine, pyroxene, plagioclase, and chromite) compared to $\mathrm{K}_{2} \mathrm{O}$, and because $\mathrm{Zr}$ is less likely than $\mathrm{K}_{2} \mathrm{O}$ to have been affected by hydrothermal alteration.

The mineral assemblages tested in the PER diagrams are combinations of the minerals olivine, plagioclase, and clinopyroxene, which were determined by petrographic observations to be most significant in the MSP. Other minerals in the samples (chromite, orthopyroxene, amphibole, phlogopite) are relatively minor components, and/or appear late in the crystallization sequence. On a PER assemblage diagram with axes selected to test for fractional crystallization of olivine, plagioclase, and clinopyroxene, the MSP samples plot just below a line with a slope of 1(Fig. 7) due to the presence of sub-calcic pyroxene. This trend is consistent with fractional crystallization of this assemblage, as the axes of the diagram were selected so that fractionation of the tested assemblage displaces the data along a line with a slope of 1 . The data also form a line with a slope of 1 on a PER assemblage diagram testing fractional crystallization of olivine and plagioclase (Fig. 8). On this diagram, crystallization of orthopyroxene and/or clinopyroxene have cancelling effects, and so the good fit of the data to the line is consistent with the interpretation that the bulk of the compositional variation in the MSP can be attributed to a combination of olivine and plagioclase fractional crystallization, with the crystallization of clinopyroxene and orthopyroxene being less important. The axes selected for Figure 9 also are not affected by clinopyroxene crystallization, and hence this diagram further reveals the relative involvement of olivine and plagioclase in fractional crystallization. On this diagram, the peridotitic rocks, as well as some troctolitic and olivine-bearing gabbroic rocks, display a trend with the slope of 8 , indicating that these rocks fractionated olivine and plagioclase in the ratio 8:1 (89\% olivine and 11 $\%$ plagioclase). A shorter and shallower trend with a slope of $1 \frac{12}{2}$ is also observed in the other rock types, which corresponds to minor fractional crystallization of a 2:1 ratio of plagioclase to olivine. A plot of $\mathrm{Fe} / \mathrm{Zr}$ vs. $\mathrm{Mg} / \mathrm{Zr}$ (Fig. 10a) suggests that the fractionating olivine had a composition of $\mathrm{Fo}_{83-77}$, consistent with the range of olivine compositions obtained by electron microprobe analysis (Grammatikopoulos 1992; Hiebert 2005;
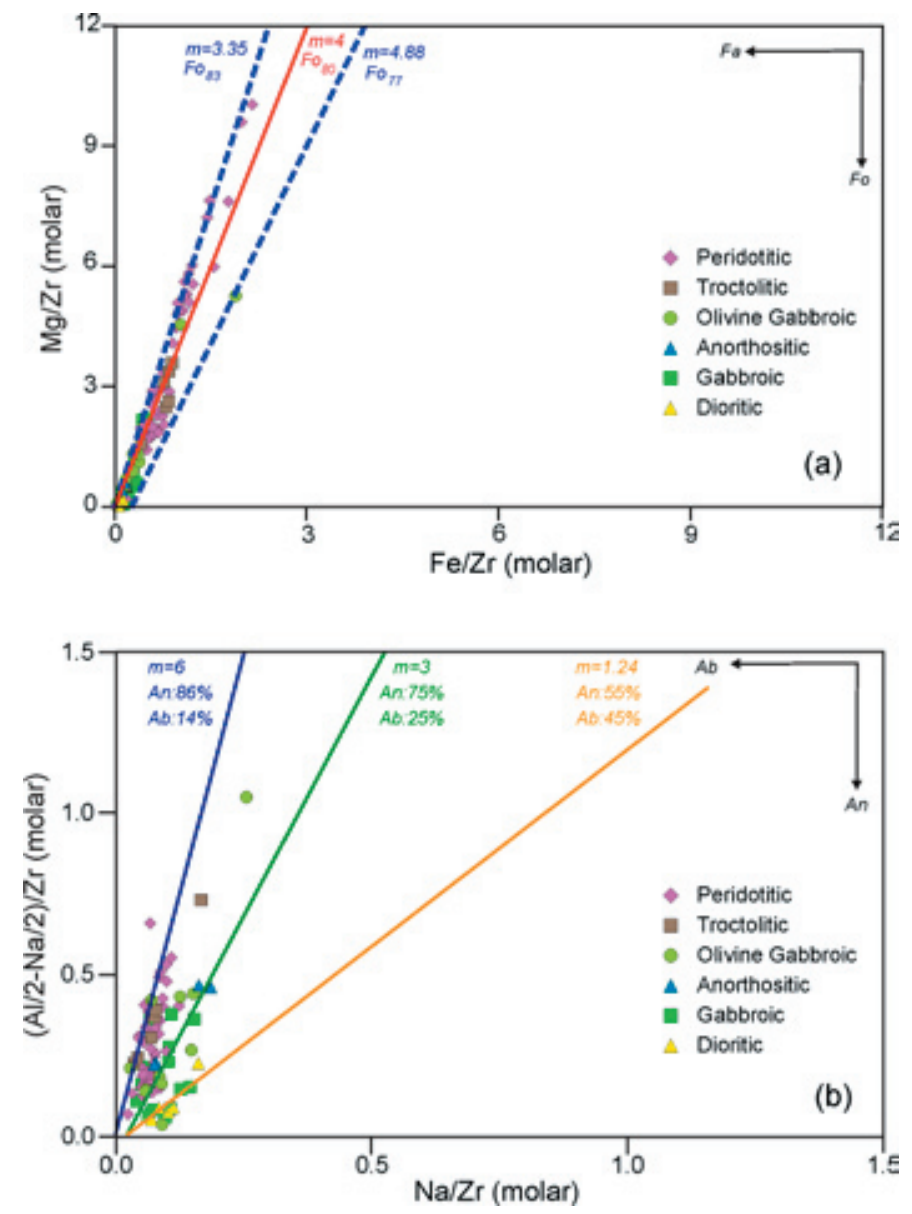

Fig. 10. (a) Plot of molar $\mathrm{Mg} / \mathrm{Zr}$ against Fe/Zr, indicating that the composition of fractionating olivine varied between $\mathrm{Fo}_{77}$ and $\mathrm{Fo}_{83}$. (b) Plot of molar (Al/2 - Na/2)/Zr against $\mathrm{Na} / \mathrm{Zr}$, showing that the composition of fractionating plagioclase varied from $A n_{86}$ to $A n_{75}$, with a later generation of plagioclase of composition $\mathrm{An}_{55}$.

Table 1). An analogous diagram for plagioclase (Fig. 10b) suggests that fractionating plagioclase compositions were in the range of $\mathrm{An}_{86-75}$. Another, less prominent trend in some gabbroic and dioritic samples indicates a composition of $\sim \mathrm{An}_{55}$. These separate trends indicate two generations of plagioclase crystallization in the MSP. The first more calcic plagioclase generation $\left(\mathrm{An}_{86-75}\right)$ was involved in the crystal fractionation processes in the MSP magma and occurs as a cumulate phase in peridotitic, olivine-bearing gabbroic, troctolitic, anorthositic, and some gabbroic samples. In contrast, the second generation of less calcic plagioclase crystallized as an interstitial phase in peridotitic, olivine-bearing gabbroic, troctolitic, anorthositic, and some gabbroic samples, and had only minor control on the chemical variation in the predominantly gabbroic and dioritic rocks. 


\section{Ni-Cu-PGE MINERALIZATION}

Sulphide-bearing zones with interstitial pyrrhotite, chalcopyrite, pentlandite, and pyrite occur mainly in periditotic rocks (e.g., Fig. 5), although some dioritic samples from the western part of the MSP contain up to 5\% interstitial chalcopyrite and pyrrhotite by volume, as well as blebs and stringers of those minerals. Several PGE-bearing horizons have been identified in the MSP, with highest $\mathrm{Pt}+\mathrm{Pd}$ grades of $2.44 \mathrm{ppm}(0.74 \mathrm{Pt}$ $+1700 \mathrm{Pd}$ ) in drill core, and $5.7 \mathrm{ppm} \mathrm{Pt+Pd}$ in a grab sample (Warner 1997; Paktunc 2000). These horizons typically occur within peridotitic lithologies (Fig. 5), and were interpreted by Paktunc (2000) to occur at the base of these units. The PGEbearing horizons in the MSP are not associated with chromitite as in the major reef deposits in the Bushveld and Stillwater complexes (Naldrett 1989), but instead occur with Ni-Cu sulphide-bearing horizons that do not contain significantly more chromite that other peridotitic rocks (Grammatikopoulos et al. 2007). Details of distribution, textural relationships, and paragenesis of the sulphide and PGE minerals were presented by Grammatikopoulos et al. (2007).

The apparent lack of well-developed layering in the MSP suggests that the most efficient concentration of PGE-mineralization may not have occurred in the most primitive (most mafic and ultramafic) parts of the pluton. The MSP may have more significant PGE-mineralization in other areas than the pseudolayered volume represented by the drill core. Mineralization in the MSP might be analogous to that in the Lac des Isles Complex north of Thunder Bay, Ontario, in which PGE mineralization forms irregular pods and discontinuous bands associated with $<1$ to $10 \%$ by volume $\mathrm{Cu}$-rich sulphide minerals along contacts between different lithologies (Sutcliffe et al. 1989; Brügmann et al. 1989, 1997; Peck et al. 2001). Mineralization in the Lac des Isles Complex is associated commonly with magmatic breccia containing zones of mafic pegmatite, and hydrous mafic minerals are common in mineralized rocks (Sutcliffe et al. 1989; Brügmann et al. 1989, 1997; Peck et al. 2001). Mineralization is of highest grade in gabbroic rocks in the southern part of the complex, although low-grade PGE horizons exist in the layered northern ultramafic centre (Brügmann et al. 1989). One model for the genesis of this style of mineralization, presented by Watkinson et al. (2002), interpreted it to have formed by the movement of high-temperature deuteric fluid through semi-crystalline magma, enhancing crystallization, to form mafic pegmatite and vari-textured gabbro, and producing sulphide-poor, PGErich mineralization.

The presence of primary hydrous minerals in the MSP suggests that the volatile content may have been high enough for a high-temperature deuteric fluid to exsolve late in its evolution, capable of forming mineralization similar to that in the Lac des Isles Complex. The poorly exposed western part of the MSP appears to be mainly dioritic and gabbroic and contains disseminated sulphide mineralization, hydrous silicate minerals (hornblende), and plagioclase-rich lithologies, as well as pegmatitic textures and magmatic breccia. Hence this part of the MSP may have potential for PGE mineralization like that found within the southern part of the Lac des Isles Complex.

\section{MAGMA GENERATION AND EVOLUTION}

The parent magma of the MSP likely was not a primary depleted mantle-derived magma, as demonstrated by the $\varepsilon \mathrm{Nd}(\mathrm{t})$ value of 1.3 from dioritic units of the MSP reported by Samson et al. (2000). Rhyolite, dacite, and basalt of the host Coldbrook Group also yielded similar $\varepsilon N d(t)$ values of -1.6 to 3.4, which suggest that the source for both the MSP and Coldbrook Group magmas was a combination of mantle and crustal material. Furthermore, olivine compositions $\left(\mathrm{Fo}_{83-80}\right)$ in the MSP (Table 1) are too fayalitic to have been formed in a melt directly from the mantle $\left(\sim \mathrm{Fo}_{90}\right.$; Grove 2000$)$. Olivine compositions suggest that fractionation of mafic minerals, such as a previous generation of olivine, or assimilation of crustal material, occurred prior to emplacement of the MSP. These processes likely occurred in a deeper magma chamber, where the mantle-derived magma was at neutral buoyancy, producing a less dense magma, which then rose to form the MSP. If this deeper magma chamber was periodically tapped, then magmas of different compositions would have been emplaced into the MSP magma chamber. This process in combination with crystal fractionation would have led to the complex and laterally discontinuous lithological variations in the MSP. One such tapping of the deeper magma chamber late in its evolution may have been more evolved magma that crystallized to form the dioritic rocks in the western portion of the MSP. This magma may have also produced the dioritic dykes observed in drill core, although it is also possible that these dioritic layers represent segregations of residual melt trapped in the cumulate pile.

Grammatikopoulos (1992) and Grammatikopoulos et al. (1995) interpreted olivine and pyroxene fractionation to be important processes in the formation of the peridotitic lithologies. However, the presence of olivine as the dominant cumulate mineral, as well as the PER diagram analysis, suggests that olivine fractionation was the main process. Grammatikopoulos (1992) also interpreted plagioclase fractionation to be important in the formation of the other lithologies, an interpretation supported by the PER diagrams in this study. The presence of abundant hydrous minerals in peridotitic rocks (phlogopite; Fig. 4b) as well as in gabbroic and dioritic rocks (hornblende; Fig. 4f) suggests that the parent magma contained a relatively high concentration of water, as also suggested by Grammatikopoulos (1992) and Grammatikopoulos et al. (1995).

Although localized evidence for layering is present in the MSP, and many samples have evidence for cumulate textures, no evidence of regularity or cyclicity in the distribution of petrologic assemblages is evident (Tables 2, 3). However, the localized areas where continuous layering is present contain the PGE-bearing horizons in the MSP. Hence special condi- 
tions apparently existed in the magma chamber at times in the crystallization history, allowing the formation of PGE-bearing horizons that apparently were not formed at any other time. However, that layering is present only locally implies that such conditions did not exist in the MSP during the bulk of the crystallization history. The magma chamber displays strong local variation in magma composition resulting in a lack of large-scale, consistent, layering. Multiple magma injections, as shown by magmatic scour structures (Grammatikopoulos 1995; Paktunc 2000), may have also disrupted crystallization and inhibited the development of large-scale layering.

\section{CONCLUSIONS}

Compositional variation in the MSP is predominantly a result of olivine and plagioclase fractional crystallization, with a smaller contribution from clinopyroxene fractional crystallization. The parent magma of the MSP was not derived directly from the mantle, but likely underwent olivine fractional crystallization and/or crustal assimilation in a deeper magma chamber prior to emplacement in the MSP magma chamber, including a later injection that formed the diorite to the east and diorite dykes throughout the MSP. Laterally continuous layering is present in the MSP only very locally, suggesting that unique conditions existed in the magma chamber at these times. PGE-bearing horizons are also present in these layered horizons; however, by analogy with the Lac des Isles Complex, the highest grade PGE mineralization may be as yet undiscovered in the western part of the MSP.

\section{ACKNOWLEDGEMENTS}

This paper is based on the MSc thesis by the senior author. We thank Malcolm McLeod, Susan Johnson, and Maurice Mazerolle of the New Brunswick Department of Natural Resources for their assistance. The work was funded by a grant from the New Brunswick Department of Natural Resources and the Natural Sciences and Engineering Research Council of Canada (NSERC). Jeffrey Bigelow and Heather Wolczanski assisted with field work in the summer of 2004. We thank Tassos Grammatikopoulos for providing an introduction to the pluton and encouragement throughout the project. We are grateful to journal reviewers Malcolm McLeod and Trevor McHattie, and editor Rob Fensome, whose comments and suggestions led to improvements in the manuscript.

\section{REFERENCES}

BARR, S.M., AND WhITE, C.E. 1999. Field relations, petrology, and structure of Neoproterozoic rock in the Caledonian Highlands, southern New Brunswick. Geological Survey of Canada Bulletin 530, $101 \mathrm{p}$.

BARR, S.M., AND WHITE, C.E. (compilers) 2004. Bedrock geol- ogy of the Caledonian Highlands of southern New Brunswick. New Brunswick Department of Natural Resources, Minerals, Policy and Planning Division, Plate 2004-138, scale 1:100 000 .

Barr, S. M., Bevier, M. L., White, C. E., And Doig, R. 1994. Magmatic history of the Avalon terrane of southern New Brunswick, Canada, based on U-Pb (zircon) geochronology. Journal of Geology, 102, pp. 399-409.

Brügmann, G.E., Naldrett, A.J., And MacDonald, A.J. 1989. Magma mixing and constitutional zone refining in the Lac des Iles Complex, Ontario: genesis of platinumgroup element mineralization. Economic Geology, 84, pp.1557-1573.

Brügmann, G.E., Reischmann, A., Naldrett, A.J., AND Sutcliffe, R.H. 1997. Roots of an Archean volcanic arc complex: the Lac des Iles area in Ontario, Canada. Precambrian Research, 81, pp. 223-239.

Grammatikopoulos, A.L. 1992. Petrogenesis, age, and economic potential of gabbroic plutons in the Avalon terrane in southern New Brunswick and southeastern Cape Breton Island. Unpublished M.Sc. thesis, Acadia University, Wolfville, Nova Scotia, 378 p.

Grammatikopoulos, A.L., Barr, S.M., Reynolds, P.H., AND Doig, R. 1995. Petrology and age of the Mechanic Settlement Pluton, Avalon terrane, southern New Brunswick. Canadian Journal of Earth Sciences, 32, pp. 2147-2158.

Grammatikopoulos, T.A., Barr, S.M., Hiebert, R.S., Stanley, C.R., and Valeyev, O. 2007. Cu-Ni and PGE minerals in the Mechanic Settlement Pluton, southern New Brunswick, Canada. The Canadian Mineralogist, 45, pp. 775-792.

Grove, T.L. 2000. Origin of magmas. In Encyclopedia of Volcanoes. Edited by H. Sigurdsson. Academic Press, pp. 133-148.

Hibbard, J.P., van StaAl, C.R., Rankin, D., ANd Williams H. 2006. Lithotectonic map of the Appalachian orogen (north), Canada-United States of America. Geological Survey of Canada Map 02041A, scale 1:1500 000.

Hiebert, R. 2005. Petrogenesis of the Mechanic Settlement Pluton, southern New Brunswick, and controls on associated PGE mineralization. Unpublished MSc thesis, Acadia University, Wolfville, Nova Scotia, 232 p.

NALDRETt, A.J. 1989. Magmatic sulphide deposits. Oxford Monographs on Geology and Geophysics, No. 14, 186 p.

Paktunc, A.D. 1988. Mafic-ultramafic rocks in New Brunswick and their platinum-group element potentials. In Thirteenth annual review of activities. Edited by S.A. Abbot. New Brunswick Department of Natural Resources and Energy, Minerals and Energy Division, Information Circular 88-2, pp. 152-155.

PakTUnC, A.D. 1989. Platinum-group element mineralization in the Mechanic Settlement Intrusion, Kings County, New Brunswick (MDA). In Fourteenth annual review of activities. Edited by S.A. Abbot. New Brunswick Department of Natural Resources and Energy, Minerals and Energy Division, Information Circular 89-2, pp. 213-214. 
Paktunc, A.D. 2000. Petrology of the Mechanic Settlement Pluton and related platinum-group element mineralization. Exploration and Mining Geology, 9, pp. 157-170.

Paktunc, A.D., Ketchum, J., and Watanabe, D. 1989. Geology of the Mechanic intrusion. Geological Survey of Canada Open File 2024, scale 1:10 000.

Pearce, T.H. 1968. A contribution to the theory of variation diagrams. Contributions to Mineralogy and Petrology, 19, pp. 142-157.

Peck, D.C., Keays, R.R., James, R.S., Chubb, P.T, and ReEves, S.J. 2001. Controls on the formation of contacttype platinum-group element mineralization in the East Bull Lake Intrusion. Economic Geology, 96, pp. 559-581.

Ross, S. 2000. Introduction to probability models. $7^{\text {th }}$ Edition. Academic Press, Burlington, Massachusetts. 782 p.

Ruitenberg, A.A., Giles, P.S., Venugopal, D.V., Buttimer, S.M., McCutcheon, S.R., And Chandra, J. 1979. Geology and mineral deposits, Caledonia area, New Brunswick. New Brunswick Department of Natural Resources, Memoir $1,213 \mathrm{p}$.

SAMson, S.D., Barr, S.M., and White, C.E. 2000. Nd isotopic characteristics of terranes within the Avalon Zone, southern New Brunswick. Canadian Journal of Earth Sciences, 37, pp. 1039-1052.

Stanley, C.R. 1998. Graphical investigation of lithogeochemical variations using molar element ratio diagrams; theoretical foundation. I $n$ Lithogeochemical Exploration for Metasomatic Zones Associated with Hydrothermal Mineral
Deposits using Molar Element Ratio Analysis. Edited by C.R. Stanley. Mineral Deposits Research Unit, Lithogeochemical Exploration Research Project, University of British Columbia, Short Course Notes, February 1998, pp. 63-103.

Stanley, C.R., And Russell, J.K. 1989. Petrologic hypothesis testing with Pearce Element Ratio diagrams: derivation of diagram axes. Contributions to Mineralogy and Petrology, 103, pp. 78-89.

StreckeIsen, A. 1976. To each plutonic rock its proper name. Earth Science Reviews, 12, pp.1-33.

Sutcliffe, R.H., Sweeney, J.M., And Edgar, A.D. 1989. The Lac des Iles Complex, Ontario: petrology and platinum-group-elements mineralization in an Archean mafic intrusion. Canadian Journal of Earth Sciences, 26, pp. $1408-1427$.

Warner, T.L. 1997. Assessment report on the Mechanic Settlement claim group, Mechanic Settlement, NB. New Brunswick Department of Natural Resources, Assessment File 474865.

Watkinson, D.H., Lavigne, M.J., and Fox, P.E. 2002. Magmatic-hydrotherman $\mathrm{Cu}$ - and Pd-rich deposits in gabbroic rocks from North America. In The geology, geochemistry, mineralogy, and mineral beneficiation of PGE. Edited by Louis J. Cabri. CIM Special Volume 54, pp. 299-319.

Wells, S. 1992. Report of work 1990-1991, Mechanic Settlement property, Kings County, New Brunswick. New Brunswick Department of Natural Resources, Assessment File 474252. 